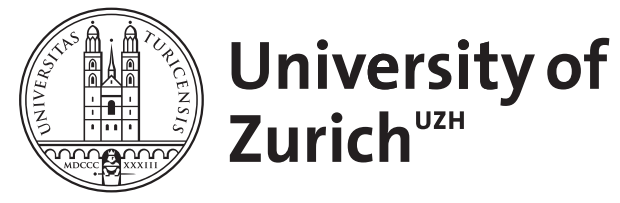
Archive

University of Zurich

University Library

Strickhofstrasse 39

CH-8057 Zurich

www.zora.uzh.ch

Year: 2015

\title{
Standard-essential patents in standard setting organizations: competition law and the realization of licensing commitments
}

\author{
Heinemann, Andreas
}

DOI: https://doi.org/10.1093/jiplp/jpv178

Posted at the Zurich Open Repository and Archive, University of Zurich ZORA URL: https://doi.org/10.5167/uzh-118770

Journal Article

Accepted Version

Originally published at:

Heinemann, Andreas (2015). Standard-essential patents in standard setting organizations: competition law and the realization of licensing commitments. Journal of Intellectual Property Law Practice, 10(12):947-952.

DOI: https://doi.org/10.1093/jiplp/jpv178 


\section{Andreas Heinemann*}

\section{Standard-essential patents in standard setting organizations: competition law and the realization of licensing commitments ${ }^{* *}$}

\section{Problem and Facts}

\section{Fundamental Constellation}

The judgment handed down by the Court of Justice of the European Union (hereinafter: CJEU) in Huawei Technologies concerns Art. 102 TFEU, i.e. the ban on abusing a dominant position in European competition law. Is a patent proprietor in breach of this provision when it sues an alleged patent infringer for injunctive relief, although the patent proprietor promised a licence and although the alleged infringer declared itself willing to enter into a licensing agreement? This general question typically arises in the following guise where standardisation is concerned: When developing technical standards within the context of recognized Standard Setting Organizations (e.g. in Europe CEN,CENELEC and the ETSI relevant in the present context $^{1}$ ), nowadays the participating enterprises are normally urged to issue a FRAND declaration, namely to commit to licensing pertinent intellectual property rights to all interested parties at fair, reasonable and non-discriminatory terms. ${ }^{2}$ The aim is to avoid standardisation participants enticing the relevant industry into a patent ambush in which the relevant industrial property rights are initially concealed before being disclosed following acceptance of the standard, in order to demand excessive licence fees. ${ }^{3}$

\section{Complications}

The FRAND commitment practice has in fact defused the problem of opportunistic behaviour within standardisation institutes. Spectacular cases of ambushing such as Rambus ${ }^{4}$ have remained the exception. However, problematic consequences have arisen: Since "FRAND" is an undefined term and no particular effort has been made to specify it in further detail, dispute

\footnotetext{
* Prof. Dr., University of Zurich, Vice-President of the Swiss Competition Commission - comment on CJEU judgment of 16 July 2015, case C-170/13, ECLI:EU:C:2015:477 - Huawei Technologies (hereinafter: CJEU Huawei). The author is expressing his personal opinion.

${ }^{* *}$ Translated into English by Catriona Thomas, MA MCIL, Karlsruhe, Germany.

${ }^{1}$ European Telecommunications Standards Institute.

${ }^{2}$ FRAND: Fair, Reasonable and Non-Discriminatory, see in detail Weber, 34 World Competition 51 (2011). The standards-related FRAND declaration has to be distinguished from the declaration of willingness to license under patent law in accordance with Sec. 23 of the German Patent Act (PatG) and Art. 8 of the EU Regulation on Unitary Patent Protection (Regulation (EU) No. 1257/2012): FRAND declarations are issued within the context of standardisation institutes, the declaration of willing to license under patent law is made to the Patent Office. Regarding the relationship between Sec. 23 of the German Patent Act (PatG) and FRAND declarations, see Bodewig, GRUR Int 2015, 626 (633-634).

${ }^{3}$ See the ETSI Intellectual Property Rights Policy <www.etsi.org/images/files/IPR/etsi-ipr-policy.pdf〉. According to No. 3.1 of that text, the aim is to achieve a balance between the needs of standardisation for public use and the interests of those holding intellectual property rights. The standardisation participants have to disclose essential intellectual property rights (No. 4). ETSI urges proprietors of standard intellectual property rights to issue a FRAND declaration while ensuring that the obligation is passed on to a successor in title (No. 6). If no FRAND declaration is issued, technical alternatives have to be explored. In the absence of a technical alternative the work on the relevant standard has to be discontinued (No. 8).

${ }^{4}$ European Commission, decision of 9.12.2009 - Rambus, OJ 2010 C 30/17.
} 
arises frequently about the amount of a reasonable licence fee and about the reasonableness of the other terms. ${ }^{5}$ As long as no licence agreement has been brought about, the proprietor of intellectual property rights is likely to sue enterprises already using the protected subjectmatter for infringement. However, many of the relevant intellectual property rights constitute "essential standards": It is not possible to manufacture products in line with the standards without using the relevant patent. Vertically integrated intellectual property right holders active on downstream markets that depend on the standard could therefore be tempted to refuse or delay the conclusion of licensing agreements.

\section{Factual Constellation}

The Regional Court (LG) Düsseldorf has to decide a corresponding dispute between two Chinese enterprises from Shenzhen. The focus lies on the LTE standard, i.e. the standard for fourth-generation mobile phone systems. More than 4,700 patents have been registered as standard-essential patents (SEPs) for the LTE standard. A FRAND declaration was issued to ETSI for the patent in dispute by Huawei Technologies (hereinafter: Huawei). ZTE produces base stations using LTE software, meaning that is uses all LTE-essential patents. Licensing negotiations between the two parties were unsuccessful. ZTE filed an opposition against the patent in dispute at the European Patent Office. Huawei sued ZTE for injunctive relief, presentation of accounts, recall of the product and damages. The Regional Court (LG) referred several questions to the CJEU for a preliminary ruling (Art. 267 TFEU), concerning the pivotal question whether, and if so subject to which requirements, a patent infringement action is to be considered abuse of a dominant market position in the sense of Art. 102 TFEU where a FRAND declaration was issued. ${ }^{6}$

\section{Solution Developed by CJEU: Roadmap for FRAND Cases}

\section{Negatory and Compensatory Protection}

When applying these principles the CJEU distinguishes between actions for injunctive relief and recall of a product on the one hand, and actions for the presentation of accounts and damages on the other hand. The CJEU held that the latter actions are not in breach of Art. 102 TFEU since the assertion of a claim for presentation of accounts and damages for past acts of use does not directly affect whether products of competitors that comply with the standards are put or remain on the market. ${ }^{7}$

\section{Exceptional Circumstances}

As regards actions for injunctive relief and recall of the product, the CJEU referred to its established case law, according to which "the exercise of an exclusive right linked to an intellectual-property right by the proprietor may, in exceptional circumstances, involve abusive conduct for the purposes of Article 102 TFEU". ${ }^{8}$ In the present case the CJEU

\footnotetext{
${ }^{5}$ In February 2015 the European Commission completed a public consultation on the theme "Patents and Standards" also concerning experience gained with FRAND, see further references at <http://ec.europa.eu/growth/industry/intellectual-property/patents/standards/index_en.htm>.

${ }^{6}$ Regional Court (LG) Düsseldorf, GRUR-RR 2013, 196 with comment by Hoppe-Jänisch.

${ }^{7}$ CJEU- Huawei, para. 74-75. GRUR 2015, 764.

${ }^{8}$ CJEU - Huawei, para. 47 citing the Volvo, Magill and IMS Health judgments; on this series of judgments see Heinemann, GRUR 2006, 705 (708 et seq.).
} 
affirmed the existence of exceptional circumstances, arguing as follows: Patents do not "normally" prevent third parties from manufacturing competing products since they can diverge from the patent "without compromising the essential functions of the product in question". . Where standard-essential products are concerned the situation changes since products conforming to the standard can only be manufactured using the relevant patent. Hence the proprietor of the intellectual property rights can deploy a claim for injunctive relief in order to "prevent products manufactured by competitors from appearing or remaining on the market and, thereby, reserve to itself the manufacture of the products in question."10 This is contrary to the typical quid pro quo of the case: An SEP can only be obtained against an irrevocable declaration of willingness to license at FRAND terms. Moreover, a FRAND declaration generates legitimate expectations in third parties.

\section{Requirements Made of Claim for Injunctive Relief}

The CJEU therefore held that "the abusive nature of such a refusal may, in principle, be raised in defence" to actions for injunctive relief or for the recall of products. ${ }^{11}$ However, since licences only have to be granted at FRAND terms, "a fair balance between the interests concerned" has to be established. When establishing such a balance the CJEU largely concurred with the final opinion of the Advocate General, ${ }^{12}$ while favouring the patent proprietor on several points. The patent proprietor has to observe certain requirements so that an action for injunctive relief and the recall of products will not be considered abusive. ${ }^{13}$ Prior to bringing the action the patent proprietor has to point out the patent infringement, has to indicate the patent concerned and specify the nature of the alleged infringement. If the alleged patent infringer has expressed his willingness to enter into a licensing agreement at FRAND terms, the patent proprietor has to submit a specific, written offer to license and, in particular, has to indicate the licence fee and how it will be calculated. ${ }^{14}$

The alleged patent infringer has to respond diligently to the offer and observe principles of good faith. Hence, where he does not accept the offer, the alleged infringer has to submit a specific counter-offer in line with FRAND terms at short notice. From the point at which his counter-offer is rejected, the alleged infringer already using the patent has to provide appropriate security, e.g. by providing a bank guarantee or by placing the amounts necessary on deposit. ${ }^{15}$ Precise calculations are required about use of the SEP. If the conduct of the alleged patent infringer is not in line with these requirements or delaying tactics are employed, the accusation of abuse against the patent proprietor will be dropped.

\footnotetext{
${ }^{9}$ CJEU - Huawei, para. 50.

${ }^{10}$ CJEU - Huawei, para. 52.

${ }^{11}$ CJEU - Huawei, para. 54. In this sense see the previous judgment of the Higher Regional Court (OLG) Karlsruhe, GRUR-Prax 2015, 283 (reported by Hauck).

${ }^{12}$ Advocate General Wathelet, Opinion dated 20.11.2014, ECLI:EU:C:2014:2391 - Huawei Technologies (hereinafter: AG Wathelet-Huawei).

${ }^{13}$ CJEU - Huawei, para. 55 et seq.

${ }^{14}$ The Advocate General had required the patent proprietor to submit a corresponding offer "in any event", i.e. irrespective of the express interest of the user, see AG Wathelet - Huawei, para. 85.

${ }^{15}$ The Advocate General had assumed an obligation to provide security only after an application for a decision by a court or an arbitration tribunal had been made, see AG Wathelet - Huawei, para. 93.
} 
The further specification and application of these requirements to the case at hand is the responsibility of the court referring the questions for a preliminary ruling. The CJEU also pointed out that the parties have the option of agreeing on an independent third party who determines details of the FRAND terms. Furthermore, an alleged infringer "cannot be criticised" for challenging the validity or the essential nature of the patent to the relevant standard and/or its actual use, or for reserving the right to do so in future: Standardisation institutes do not examine the validity of the relevant patents or the question whether they are in fact essential to the standard in which they are included. ${ }^{16}$

\section{Conclusion}

The CJEU has developed a FRAND-specific roadmap guiding the proprietor of an SEP past the prohibition of Art. 102 TFEU and chaperoning potential licensees towards use of the standard under a licensing agreement. If the patent proprietor disregards the guidelines, he will be in breach of competition law; if the party using the patent ignores the plan, a claim for injunctive relief under patent law will prevail.

\section{Position Among Existing Cases}

For the first time the CJEU handed down a ruling on the conformity with competition law of patent infringement actions following a commitment to license at FRAND terms. However, other courts and several cartel authorities have already addressed the issue.

\section{Compulsory Licence Under Competition Law}

In the Huawei case, the obligation of the patent proprietor to enter into a licensing agreement follows from its own FRAND commitment. ${ }^{17}$ Hence this does not involve a compulsory licence, but, rather, the fulfilment of a private, autonomous commitment assumed. The contrasting case is that of a compulsory licence under competition law, where refusal to grant a licence is considered a violation of competition law and where freedom to contract is restricted under exceptional circumstances. Where a compulsory licence under competition law is concerned, the abuse therefore arises in the refusal to grant a licence. In FRAND cases, in contrast, the assertion of a claim for injunctive relief despite a declaration of willingness to license is considered to constitute abuse. ${ }^{18}$

As regards the requirements of a compulsory licence under competition law, orientation was provided by the CJEU in the Magill ${ }^{19}$ and IMS Health ${ }^{20}$ cases. The German Federal Court of

\footnotetext{
${ }^{16}$ CJEU-Huawei, para. 68-69.

${ }^{17}$ In accordance with the prevailing opinion, FRAND commitments should be considered binding under civil law, e.g. as a contract for the benefit of a third party or as an offer ad incertas personas. According to opposing views, however, a mere pactum de negotiando, a pactum de non petendo or even invitatio ad offerendum are assumed; see references in Körber, Standardessentielle Patente, FRAND-Verpflichtungen und Kartellrecht, 2013, 38 et seq.; Maaßen, Normung, Standardisierung und Immaterialgüterrechte, 2006, 317 et seq.; Tapia, Industrial Property Rights, Technical Standards and Licensing Practices (FRAND) in the Telecommunications Industry, 2010, 18 et seq.

${ }^{18}$ See also Picht, GRUR Int 2014, 1 (11-12), who classifies the subsequent refusal to grant a licence despite a FRAND commitment to be exclusionary abuse in the sense of Art. 102 TFEU; the CJEU was not asked to express an opinion on this question.

${ }^{19}$ CJEU, GRUR Int 1995, 490 - Magill TV Guide.

${ }^{20}$ CJEU, GRUR 2004, 524 - IMS Health. Also important: judgment of the Court of First Instance (Grand Chamber), ECLI:EU:T:2007:289 - Microsoft v Commission. Regarding the unresolved issues see
} 
Justice (BGH) clarified that the defence of a compulsory licence under competition law can be raised directly in infringement proceedings. ${ }^{21}$ Yet according to the Orange Book Standard judgment, this applies to a claim for injunctive relief only if the user makes an unconditional offer for the conclusion of a licensing agreement and pays or deposits the prospective licence fees. An offer will only be considered unconditional provided the user does not challenge the validity of the intellectual property right and does not deny the infringement. ${ }^{22}$

Although the Orange Book Standard judgment did not concern a FRAND commitment, but a compulsory licence under competition law relating to a de facto standard, the judgment did exercise a considerable influence on the discussion concerning FRAND cases. The strict requirements of the German Federal Court of Justice (BGH) contradict the approach adopted by the European Commission to solving the problem - which will be discussed below. The conflict between the two concepts is of pivotal significance to the decision of the Regional Court (LG) Düsseldorf to refer questions to the CJEU for a preliminary ruling in the Huawei case. $^{23}$

\section{FRAND Commitment}

\section{a) Horizontal Guidelines of the European Commission}

In its Horizontal Guidelines dating from 2010 the European Commission defined a safe harbour for standardisation agreements. According to the Horizontal Guidelines, there is no restriction of competition in the sense of Art. 101(1) TFEU where participation in the setting of standards is unrestricted and transparent, where standardisation agreements contain no obligation to comply with the standard and provide access to the standard on fair, reasonable and non-discriminatory terms while containing an IPR policy for the disclosure of pertinent intellectual property rights in good faith. ${ }^{24}$ Failure to observe these requirements does not automatically mean that the relevant standardisation agreements are in breach of competition law. Rather, examination of the individual case at hand is required.

\section{b) Motorola Mobility and Samsung}

In the Motorola Mobility case the European Commission held that a request made for injunctive relief under patent law despite a FRAND commitment was to be considered abuse of a dominant position on the market if the user is willing to enter into a licensing agreement. ${ }^{25}$ However, no fine was imposed: the Commission held that so far there was no case law from the EU courts and that the courts in the Member States had reached different conclusions so far. ${ }^{26} \mathrm{~A}$ restriction of competition was also held to arise where the opponent

\footnotetext{
Ullrich/Heinemann in Immenga/Mestmäcker (Eds.), Wettbewerbsrecht, Vol. 1. EU/Part 2, 5th ed. 2012, GRUR B, No. 58 et seq.

${ }^{21}$ German Federal Court of Justice (BGH), GRUR 2004, 966 (970) - Standard-Spundfass (regarding the claim for damages).

${ }^{22}$ German Federal Court of Justice (BGH), GRUR 2009, 694 - Orange-Book-Standard.

${ }^{23}$ See decision of Regional Court (LG) Düsseldorf, GRUR-RR 2013, 196 (197-198) - Huawei Technologies.

${ }^{24}$ European Commission, Guidelines on the applicability of Article 101 of the Treaty on the Functioning of the European Union to horizontal co-operation agreements dated 14.12.2010, OJ $2011 \mathrm{C}$ 11/1, para. 277 et seq.

${ }^{25}$ European Commission, OJ 2014 C 344/6 - Motorola (summary).

${ }^{26}$ Ibid., para. 25.
} 
was prevented from challenging the validity of the relevant intellectual property rights or from raising the defence of non-infringement.

The Samsung proceedings were concluded on the basis of the same line of arguments by way of commitments assumed in accordance with Art. 9 of Regulation No. 1/2003. ${ }^{27}$ In this case, the European Commission has developed a safe harbour for potential licensees. It definitely assumes a genuine interest of the user in concluding a licensing agreement if a maximum period of 12 months is set for the duration of the licence negotiations and if the parties accept that the terms will be determined by a court or - upon mutual agreement - by an arbitration tribunal, should those negotiations fail. ${ }^{28}$

\section{Conclusion}

The Huawei judgment of the CJEU (indirectly) confirms the previous practice of the European Commission. In order to avoid an accusation of abuse of a dominant position on the market, the proprietor of an SEP has to present an offer at FRAND terms to interested parties. It is not the potential licensee's responsibility to make an offer. The CJEU provides specific guidelines as to the procedure to be adopted where agreement cannot be reached on the reasonable nature of contractual terms.

The negative wording of the answer to the questions referred is conspicuous: Although the Court assumes that actions for injunctive relief and recall of a product against users who are willing to license are in principle abusive in FRAND cases, ${ }^{29}$ it denies the existence of abuse where a number of (positively worded) requirements are met. In contrast, the Advocate General proposed that abuse be affirmed where certain (negatively worded) requirements are met. A comparison of the answers reveals that the Court placed considerable emphasis on the finding that actions for patent infringement are not in breach of Art. 102 TFEU provided certain requirements are met.

\section{Assessment}

The judgment handed down by the CJEU demonstrates the effort made to establish a fair balance between patent law and competition law. ${ }^{30}$ Indeed, the FRAND cases present a (new) paradigm for the (old) conflict between these two areas of law. ${ }^{31}$ In the past, attempts were made to resolve the tension by way of delimitation provisions. According to the theory of the specific subject-matter, competition law was not to be applicable to conduct covered by the specific subject-matter of the intellectual property right. This would be relevant in the present case: According to established case law, the specific subject-matter of a patent includes "the

\footnotetext{
${ }^{27}$ European Commission, OJ 2014 C 350/8 - Samsung (summary).

${ }^{28}$ Ibid., para. 15 et seq.

${ }^{29}$ CJEU - Huawei, para. 54.

${ }^{30}$ See, for example, $C J E U$ - Huawei, para. 42: "[T] competition [...] and the requirement to safeguard that proprietor's intellectual property rights and its right to effective judicial protection".

${ }^{31}$ See the fundamental studies by Appl, Technische Standardisierung und Geistiges Eigentum, 2012; Körber (supra note 17); Picht, Strategisches Verhalten bei der Nutzung von Patenten in Standardisierungsverfahren aus der Sicht des europäischen Kartellrechts, 2013.
} 
right to oppose infringements". ${ }^{32}$ However, the term "specific subject-matter" is not mentioned in the Huawei judgment. Instead, the arguments are based on the overall context. The fact that no preferential rules were applied (whether in favour of patent law or of competition law) is to be welcomed since this enables the establishment of a fair balance between both areas of law. ${ }^{33}$

The depiction of the typical overall situation is also appropriate. The FRAND cases do not just concern individual technical achievements, but, rather, the collective setting of standards within standardisation institutes, which leads to the joint configuration of fundamental product qualities by competitors. As shown by glancing at the IP policy of the standardisation institute responsible in the present case, ${ }^{34}$ a "normal" patent becomes an SEP within the context of a reciprocal transaction: An SEP can only be obtained against an assurance of willingness to license at FRAND terms. ${ }^{35}$ If there is no willingness to license, an alternative will be sought, i.e. a standard developed which does not require the relevant patent. The deal is thwarted if the patent proprietor assumes an undertaking to grant licences but fails to fulfil it. On the other hand, a user of a patent who merely pretends to be interested in obtaining a licence without any serious interest in it, does not become a victim of abuse.

Before this backdrop, the fact that the Court imposed an obligation on the patent proprietor, and not on the potential licensee, to submit a specific offer to license at FRAND terms, is convincing. This is in line not only with customary practice in the industry, but also creates a better balance between the negotiating positions of both parties. Furthermore, the patent proprietor can best judge whether his offer corresponds to the terms he proposed to third parties, which is important owing to the ban on discrimination imposed on him under the FRAND commitment (and Art. 102(2)(c) TFEU). ${ }^{36}$ What also speaks in favour of the Huawei judgment is the best possible innovation incentives it enables for all participants: The patent proprietor receives royalties for his invention that are in line with the terms he promised. Other market participants are not prevented from implementing the standard or from developing follow-up innovations in which they invest while relying on reasonable access to the standard. It is important to prevent the users of patents from merely pretending to be interested in concluding licensing agreements. However, this risk can be alleviated by detailed requirements made of the prospective licensee's genuine interest.

\section{Outlook}

Within the scope of application of FRAND commitments, competition law can lead to a restriction of protection to compensatory claims, i.e. can exclude injunctive relief. Competition law is used to obtain a result that follows in common law from general principles of equity. ${ }^{37}$ However, the solution based on competition law is based on Art. 102 TFEU so that from the outset it is limited to enterprises occupying a dominant position on the market.

\footnotetext{
${ }^{32}$ See, e.g., CJEU, ECLI:EU:C:1992:73 para. 17 - Commission v Italy.

${ }^{33}$ See on outdated fundamental concepts as applied to SEPs Heinemann, MR-Int 2014, 85 (91-92).

${ }^{34}$ See supra note. 3 .

${ }^{35}$ According to the analysis in $C J E U$ - Huawei, para. 51.

${ }^{36}$ See CJEU - Huawei, para. 64.

${ }^{37}$ Regarding the possibility of transposing the US four-factor test into EU law see Ohly, FS Ullrich, $2009,257$.
} 
The judgment only directly affects SEPs within standardisation institutes, but it will also have other implications.

\section{Consequences in Practice}

In order to avoid a violation of competition law, proprietors of SEPs would be well-advised to follow the roadmap provided by the CJEU, i.e. to avoid rash injunctive relief and to first make a specific offer to license. Users of the standard have to participate constructively. Damages for the past use of an IP right can be demanded by a patent proprietor without conflict with competition law arising.

The Huawei judgment only relates to cases where the proprietor of an SEP has made a commitment to license at FRAND terms. However, it can be transposed to constellations involving compulsory licensing under competition law since the prospective licensee who becomes a victim of an anti-competitive refusal to license may not be placed in a position worse than someone in relation to whom a promise to license is not kept. The model developed by the German Federal Court of Justice (BGH) in the Orange Book Standard decision, which turns on an unconditional offer made by the potential licensee, therefore has to be replaced by a concept requiring the proprietor of IP rights to make an offer at reasonable terms. ${ }^{38}$ Nor may users be deprived of the fundamental legal remedies, namely the possibility of challenging the validity of a patent or of denying its status as an SEP or its use.

\section{Unresolved Questions}

\section{a) Dominant Position on the Market}

The CJEU did not have to address the question of the circumstances in which the proprietor of an SEP occupies a dominant position on the market, which is fundamental to Art. 102 TFEU. ${ }^{39}$ In a comment the Advocate General stated that an SEP did not necessarily lead to an assumption of a dominant position on the market. While considering necessary to examine each individual case he admitted that an SEP does permit a (rebuttable) presumption that there is a dominant position on the market. ${ }^{40}$ In corresponding cases, therefore, the relevant markets have to be carefully defined in order to then address the question of a dominant position. ${ }^{41}$ If there are viable alternatives to the relevant standard, the patent proprietor's scope for manoeuvre is limited.

\section{b) Genuine Willingness to Obtain a Licence}

The ambit of protection against injunctive relief only covers those who genuinely seek to enter into a licensing agreement. One of the challenges in practice is, therefore, to identify genuine willingness to obtain a licence. The CJEU established several criteria, for example the obligation to make a written counter-offer within a short period of time. In a specific case, however, this will often not provide sufficient security. In this context the safe harbour

\footnotetext{
${ }^{38}$ Cf. Ullrich/Heinemann in Immenga/Mestmäcker (supra note 20), GRUR B, No. 62.

${ }^{39}$ The CJEU pointed out that the existence of a dominant position on the market was undisputed in the case at hand, see CJEU - Huawei, paras. 28, 43.

${ }^{40}$ AG Wathelet - Huawei, para. 57-58.

${ }^{41} \mathrm{Cf}$. on the relevant issues Früh, Immaterialgüterrechte und der relevante Markt, 2012.
} 
developed by the European Commission in the Samsung case therefore appears to provide assistance. ${ }^{42}$ It appears to be supported by the reference made by the CJEU, that the parties are able to agree on resolution of the dispute by an independent third party by way of arbitration. $^{43}$

\section{c) Specification of FRAND Terms}

This leads us to the core issue, namely the substance of the FRAND terms. The standardisation institutes failed to specify this vague term in sufficient detail. ${ }^{44}$ In some cases it would be possible to avoid disputes under competition law by way of more clear-cut requirements. ${ }^{45}$ The standard setting organizations should therefore define the substance of FRAND terms in more detail and establish appropriate procedures to this end. ${ }^{46}$ Admittedly, conflicts of interest do arise, but they can be regulated. It does not seem logical to want to resolve the ambushing problem on the basis of FRAND commitments without regulating further details. Moreover, the work performed by the standardisation institutes is not intended to replace the responsibility of the cartel authorities, but, rather, to reduce the number of cases relevant under competition law.

\section{Final Remarks}

The Huawei judgment handed down by the CJEU provides new guidance for the relationship between intellectual property law and competition law. It clarifies that a solution conducive to innovation cannot be achieved by protecting intellectual property rights against competition law, but, rather, only by embracing the complementary nature of both areas of law. The judgment will exercise a strong influence on how SEPs are handled although it only directly concerns the unilateral behaviour of enterprises occupying a dominant position on the market. The right direction has been indicated; however, the roadmap developed by the CJEU is relatively vague on details. When cases are addressed in practice, numerous individual questions will arise that will have to be resolved by the parties, by standardisation organizations, arbitration tribunals and the courts as well as the competition authorities.

\footnotetext{
${ }^{42}$ See supra in front of note 28.

${ }^{43}$ CJEU - Huawei, para. 68. However, on this point the Court did not go as far as the Advocate General, who proposed that the conduct of an alleged patent infringer should not be considered to be reluctant or lacking genuine willingness if he request that the FRAND terms be determined by a court or an arbitration tribunal (AG Wathelet - Huawei, paras. 93 and 103, point 4).

${ }^{44}$ Stated expressly by the CJEU - Huawei, para. 20.

${ }^{45}$ Cf. AG Wathelet - Huawei, para. 11.

${ }^{46}$ A stronger involvement of the standardisation institutes with regard to FRAND was advocated by, e.g., Kühn/Scott Morton/Shelanski, CPI Antitrust Chronicle March 2013 (Special Issue); Picht (supra note 31), 543 et seq.; Tapia (supra note 17), 149 et seq.
} 